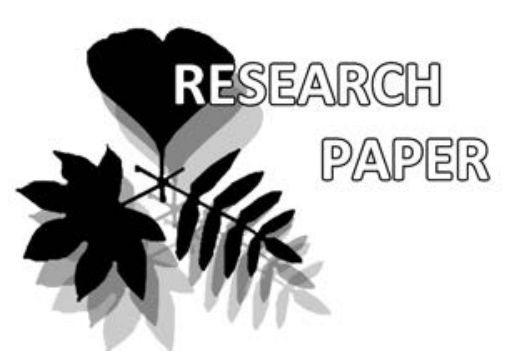

\title{
Structural changes of bark of the woody liana Toxicodendron orientale Greene (Anacardiaceae) in the extreme environments of gas- hydrothermal volcanic activity
}

\author{
Anna V. Kopanina* \& Inna I. Vlasova
}

Anna V. Kopanina*

e-mail: anna_kopanina@mail.ru

Inna I. Vlasova

e-mail: vlasova@imgg.ru

Institute of Marine geology and Geophysics FEB RAS, Yuzhno-Sakhalinsk, Russia

\section{* corresponding author}

Manuscript received: 21.11.2018

Review completed: 16.02.2019

Accepted for publication: 05.03.2019

Published online: 10.03.2019

\begin{abstract}
A B S T R A C T
We investigated the bark structure of woody liana Toxicodendron orientale Greene (Anacardiaceae) in ontogenesis and in the environmental factors of the gas-hydrothermal fields of Mendeleev volcano (Kunashir Island, Russian Far East). The following trends were found in liana ontogenesis: an increase in the diameter and length of the sieve-tube elements; sieve-tubes become rounded in cross section; an arrangement of clusters of the sieve-tube elements thereof contiguous with the axial and ray parenchyma and becomes more regular; and an increased volume of parenchyma in the conducting phloem. The age-specific transformations of the rest of the bark tissues are rather typical: dilation of the cortex parenchyma and the nonconducting phloem, sclerification of the parenchyma with isolated sclereid groups forming, obliteration of sieve-tubes etc. To study the structural changes of the bark under environmental stress, we applied a comparative analysis of age trends to a large number of bark structural traits of the Toxicodendron orientale. Such age trends were created for traits of the bark in normal and stressful environments (sea coast and volcanic landscape). The structural changes of Toxicodendron orientale in response to extreme conditions near gas-hydrothermal springs are mainly related to the conducting phloem. Comparative analysis of the functional features of this tissue shows the following important trends for plants under extreme volcanic conditions: an inversion some of traits of the bark (bark thickness, secondary and conducting phloem width, total number of phloem rays, diameter and area of the sieve-tubes elements in the conducting phloem); a decrease of diameter and increase of length of the sieve-tubes elements in the conducting phloem; a diffuse arrangement of sieve-tubes in the conducting phloem in mature plants and also; a significant amount of the uniseriate rays.
\end{abstract}

K e y w o r d s : Toxicodendron orientale, liana, bark anatomy, environmental stress, phloem, periderm, gas-hydrothermal spring, volcanic activity, age trend, structure changes

\section{P E 3 Ю M E}

Копанина А.В., ВАасова И.И. Структурные изменения коры Тохісоdendron orientale Greene (Anacardiaceae) в условиях современной газогиАротермальной вулканической активности. Изучена структура коры лианы сумаха восточного Toxicodendron orientale Greene (Anacardiaceae) в онтогенезе. Сравнительный количественный анализ анатомических признаков коры позволил определить структурные изменения в специфических условиях Верхнедокторских газогиАротермальных источников (вулк. Менделеева, о-в Кунашир). На основе структурного анализа коры в разных возрастных состояниях Аианы выявлены важные возрастные тенденции: увеличение Аиаметра и Алины члеников ситовиАных трубок; скругление ситовиАных трубок в поперечном сечении; регулярное расположение и формирование кластеров ситовидных трубок, сопряженных с аксиальной и мучевой паренхимой; увеличение объема паренхимы в проводящей флоэме. Возрастные изменения остальных тканей коры достаточно типичны: дилатация паренхимы кортекса и непроводящей флоэмы, склерефикация паренхимы с образованием изолированных склереилных групп, облитерация ситовидных трубок и Ар. А^я изучения структурных изменений коры в условиях природного стресса мы применили сравнительный анализ возрастных тренАов Аля большого числа структурных признаков коры Toxicodendron orientale. Такие тренды были построены Аля признаков коры в нормальных и стрессовых условиях (морское побережье и вулканиеский мандшафт). Структурные изменения коры Toxicodendron orientale в экстремальных условиях газогидротермальных источников в основном связаны прежАе всего с проводящей флоэмой. Сравнительный анализ функциональных особенностей этой ткани показывает слеАующие важные тенденции у растений в экстремальных вулканических условиях: инверсия некоторых признаков коры (толщина коры, ширина вторичной и проводящей флоэмы, общее количество флоэмных кучей, Аиаметр и площадь ситовидных трубок в проводящей фмоэме); уменьшение Аиаметра и увеличение Алины члеников ситовидных трубок в проводящей флоэме; Аиффузное расположение ситовидных трубок в проводящей флоэме у взрослых растений, а также значительное количество однорядных мучей.

КАючевые слова: Toxicodendron orientale, анатомия коры, флоэма, перидерма, газогиАротермальные источники, вулканическая деятельность, аАаптация 
The influence of volcanic activity on landscapes, vegetation, flora, the plant body, and its individual systems is an interesting but complex natural phenomenon, many aspects of which are still underexplored. Diverse manifestations of modern volcanic processes, such as explosive and effusive activities accompanied by pyroclastic and lava flows, ash falls, gas-hydrothermal activity, lahars, etc. transform natural habitats to various extents. The Sea-of-Okhotsk region comprising Sakhalin, the Kuril Islands and the Kamchatka Peninsula, is the only region in Russia where the active geodynamic processes of the Earth are so pronounced in the activity of volcanoes.

The influence of volcanic activity on the structure of vascular plants is poorely studied. Although many studies concern the correlations between only volcanic eruptions and features of tree rings in the context of dendrochronology (review: Schweingruber 2007), the effects of volcanism on the bark structural traits of plant tissues remain unknown. According to the Schweingruber (2007), although volcanic eruptions affect all the reaction mechanisms of trees close or far away, no relevant wood-anatomical studies exist. The following causes and effects may be expected: direct effects and indirect effects due to climate change and extreme weather conditions. The direct effect is the leaf loss due to hot ash: tree death, narrow tree rings, interruption of cell wall hickening, false rings. Another effect is related to the forming of narrow tree rings, narrow and light latewood, frost rings. Typically, volcanic eruptions give rise to single, extremely narrow tree rings, sudden phases of growth reduction, insufficient cell wall thickening and parenchymatized latewood zones. The latter are probably connected with water supply problems. The dying tissue without vessels is an adaptation to the missing water flow: small leaves, no transpiration, nowater flow, no vessels (review: Schweingruber 2007).

The current volcanic activity is very diverse. This is not only an explosive or effusive eruption, but also a variety of expressions of gas-hydrothermal and fumarole activity, which significantly transforms the landscape. The relief and vegetation have changed over the centuries. Of course, the reaction of plants to volcanic activity has common regularities as a reaction to natural stress. Our studies have shown (Poberezhnaya \& Kopanina 2011, Eryomin \& Kopanina 2012, Kopanina \& Eryomin 2011, Kopanina et al. 2015) that structural changes in the bark of woody plants under volcanic activity have also certain specifics. This not only decreases the bark width, other tissues and cells, but also increases some parameters at different ages (Kopanina et al. 2017, Kopanina 2019a,b). Such a multidirectional reaction to stress may be associated with a special regime of environmental factors in places of occurrence of gas-hydrothermal volcanic activity. These are the following factors: high temperatures of soil and the atmospheric boundary layer, toxic gas and hot steam emissions, and the relatively high concentrations of various chemical elements, including heavy metals, in water and soil.

The bark and wood anatomy of Toxicodendron Mill. and other species of the Anacardiaceae Lindl. has been reported in literature with a primary focus on verifying the taxo- nomic status of the species and the variations and forms thereof (Corothie 1960, Gibson 1981, Das 1984, De Mattos Filho 1990, Dong \& Baas 1993, Gimenez \& Moglia 1995, Terrazas \& Wendt 1995, Gupta \& Agarwal 2008, Gomez 2009, Meng et al. 2012, Eryomin \& Kopanina 2012). The ecological aspects of the structural features of the Anacardiaceae have been far less discussed in research publications with emphasis placed on the following hallmarks of structural changes in wood: the submersion tolerance of two Schinus terebinthifolius Raddi populations (Ruas et al. 2011), the ecological trends of changes in the annual height increment, and some latitude-specific vessel properties of the Brazilian species (some species of Anacardium L., Astronium Jacq., Myracrodruon Allem., Scbinus L., Tapirira Aubl. (Alves \& Angyalossy-Alfonso 2000, 2002); and the water transport in the secondary xylem of trees (some species of Gluta L., Mangifera L., Melanochyla Hook.f.) in the tropical rainforests of Borneo (Suzuki 1999). The wood anatomy of the Toxicodendron species has also been researched on account of its life forms (shrub and liana) in the determination of the structural features of the vessels and the mechanical properties of the climbing stems of Toxicodendron diversilobum (Torr. \& A. Gray) Greene (Gartner 1991). A relatively in-depth study of the phloem has been conducted into the oriental lacquer tree from China - the Toxicodendron vernicifluum (Stokes) F.A. Barkley (Meng et al. 2012). The general structure of the bark of the Toxicodendron orientale has been studied, and its traits in young and mature stems (Eryomin \& Kopanina 2012). We were the first to summarize the aspects of the ecological anatomy of the species under study, the Toxicodendron orientale (Kopanina et al. 2015).

The purpose of this paper is to study the structural response of bark, over the course of individual development of the Toxicodendron orientale Greene, to a combination of ecological factors related to the gas-hydrothermal fields of Mendeleyev Volcano on Kunashir Island (the southern Kurils). The bark traits, which change under extreme conditions such as exposure to the gas-hydrothermal springs of the active Kuril volcanoes, will be analyzed to assess the pattern and trend of structural changes of a woody plant.

\section{MATERIAL AND METHODS}

The subject of the study is the Toxicodendron orientale (Anacardiaceae), a liana (Fig. 1) or a creeping deciduous shrub with trifoliate leaves, compound sympodial paniculate axillary inflorescences, and small spherical juicy fruits. The species is widespread on the southern Kurils, the islands of Japan, and in China; it can also be found in the south of the Sakhalin island where it occurs in coniferous, mixed coniferous/broadleaved, and stone-birch forests, Kuril bamboo forests, and on sea cliffs (Nedoluzhko 1995, Eryomenko \& Barkalov 2009).

The bark samples of Toxicodendron orientale from young branches of the 1 year to mature stems (up to 15 years) we studied in details under the typical conditions of growth of the plant (normal conditions), on the Sea-of-Okhotsk coast at the foot of Mendeleyev Volcano and in landscapes altered by gas-hydrothermal fields of Mendeleyev Volcano on Kunashir Island. Those habitats of the species under con- 

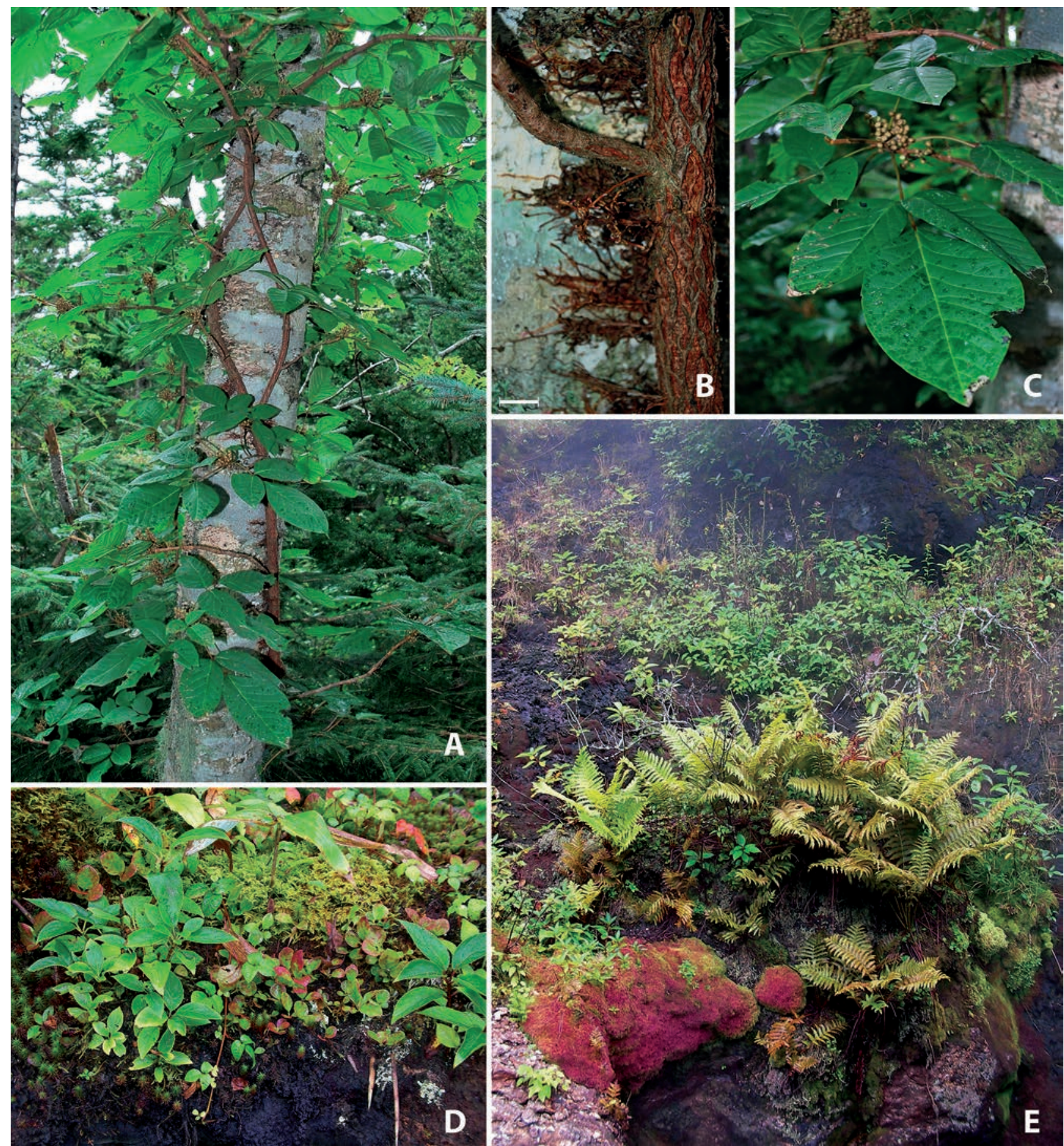

Figure 1 Toxicodendron orientale Green (Anacardiaceae) under normal and the gas-hydrothermal spring conditions of the Kunashir Island, Kuril Islands. A - Toxicodendron orientale on the trunk of the Abies sachalinensis at the foot of Mendelevev Volcano (normal conditions); B - mature stem of the Toxicodendron orientale $(1 \mathrm{~cm}) ; \mathrm{C}$ - leaf and fruits of the Toxicodendron orientale; D - Toxicodendron orientale near Kolodets spring; E the Verkhnedoktorskaya group of thermal springs at Mendeleyev Volcano, Kolodets spring

sideration are found within one altitudinal zone and one vegetation type (forest). At each sampling point, brief descriptions of plant communities and individual plant groups featuring the species under study were given. The sampling was carried out in 2006 and 2010 during the first ten days of September. Summer ends on the Kunashir Island during this period, with temperatures being nearly as high as in high summer. The Toxicodendron orientale begins to shed its leaves in late August to September, and mass leaf-fall occurs during the first and second thirds of October (Eryomenko \&
Barkalov 2009). For temperate plants it is very important to collect stem samples for anatomical analysis at the end of the growing season. At this time, the vascular cambium finishes its work and completely derived an annual growth in secondary xylem and phloem.

The Verkhnedoktorskaya group of thermal springs at Mendeleyev Volcano (Fig. 1) forms a nearly continuous discharge area extending $300 \mathrm{~m}$ along the flanks, the stream course, and in a small thermal lake (Zharkov 2014). The temperature of the ultra-acid water $(\mathrm{pH}$ is 1.6-1.9) in Lake 
Fausta ranges between 50 and $66^{\circ} \mathrm{C}$. The nearby Kolodets spring has temperatures of up to $92.4^{\circ} \mathrm{C}$ and $\mathrm{pH}$ 2.3. The gas-hydrothermal springs of the Verkhnedoktorskaya group are among the acidic nitrogen chloride-sulfate sodium hot springs containing a considerable amount of rare earth elements. Gas composition: nitric/carbonic with trace amounts of hydrogen sulfide (Bortnikova et al. 2013, Zharkov 2014). The thermal springs (the streams and lake) located 70 to $90 \mathrm{~m}$ above sea level are surrounded by a sprucebroadleaved Kuril bamboo-shrub-fern forest featuring lianas. That forest along with other variants of bambooshrub, bamboo, shrub, shrub-fern, and shrub-forb communities occupies vast areas on the lower flanks of Mendeleyev Volcano. For the Toxicodendron orientale as well as for other lianas, those variants of spruce forests made up of Picea glebnii featuring broadleaved species are the typical habitats on Kunashir Island. Found at the boundaries of gas-hydrothermal discharges are only relatively vegetative plants of Toxicodendron orientale (under 9 years) - creeping on the soil surface, ascending, and using herbs as supports. The substrate is heated, there are water and gas vapors in the atmospheric boundary layer. The stems and leaves of the Toxicodendron orientale show pronounced thermal damage and heavy protective pigmentation.

The liana samples were collected on the seashore of Cape Stolbchaty, in a shrub community featuring Pinus pumila (Pall.) Regel, Sorbus sambucifolia Cham. et Schlecht., and Hydrangea paniculata Siebold. In these environments, the Toxicodendron orientale has creeping stems supported by various shrubs and young trees such as Picea ajanensis (Lindl. et Gord.) Fisch. ex Carr., Salix caprea L. and Sasa kurilensis (Rupr.) Makino et Shibata. Some 100 to $120 \mathrm{~m}$ off the waterline, the community graduates to variations of oak forests, spruce-oak forests, and spruce-broadleaved forest communities with lianas.

A tract of forest was selected to represent "normal conditions": a broadleaved Kuril bamboo forest with Picea glehnii and Abies sachalinensis at the foot of Mendeleyev Volcano (Fig. 1), 45 to $50 \mathrm{~m}$ above sea level. Toxicodendron orientale occurs in this community as a liana attached to tree trunks and reaching a height of 7 to $10 \mathrm{~m}$.

Forest soils found outside the gas-hydrothermal discharges - on central Kunashir including seashores - show an acidic and slightly acidic reaction, a significant $\mathrm{Fe}$ and $\mathrm{Al}$ content, are potentially highly fertile, and volcanic. Remoteness from the sea and protection from cold winds and fogs play a key role in the soil processes on the island and in the formation of forest vegetation including lianas (Gladkova \& Butovets 1988).

Toxicodendron orientale samples were collected in all the studied habitats in a similar way: stem fragments from 1 to 4 years, from 5 to 8 years and from 10 to 15 years. Annual and young stems were examined in the middle internode. Between 15 and 30 stems of the three plants were taken for analysis in each habitat. The age of the stems was first determined morphologically. The age of each stem was corrected by the xylem growth rings. All samples were fixed in $96 \%$ ethanol and glycerol mixed in the ratio 3:1, and soaked in this fixative for at least two months. The samples are then processed with distilled water at least 12 hours to remove alcohol and glycerol, with the water replaced every 3 hours. The 10 to $25 \mu \mathrm{m}$-thick transverse, radial, and tangential sections of stems were cut using sledge microtome HM $430 \mathrm{c}$ with a fast-freeze device (Thermo Scientific, USA). The sections were stained with safranin and Nile blue (Prozina 1960, Barykina et al. 2004), washed in ascending alcohols with final dehydration and clarification with carbol-xylol and xylol, and mounted in a xylene-based mounting medium and Canada balsam. More than 900 transverse and longitudinal (radial and tangential) microsections were made for the purposes of this study. Thus, 50 to 70 microsections were made for analysis of each age of the annual stems and the perennial stems $(2,3,4,5,8,10,12$, and 15 years $)$ of the Toxicodendron orientale. The bark tissues were examined by the light microscope Axio Scope.A1 (Carl Zeiss, Germany). In order to measure anatomical traits and obtain microphotographs, the images were digitally processed using the Axio Vision Carl Zeiss 40v4.6.3.0 software. For the bark anatomical descriptions, we used the terminology recommended by the International Association of Wood Anatomists (IAWA) (Angyalossy et al. 2016).

The bark traits (Table 1) for the annual and perennial (2, $3,4,5,8,10,12$, and 15-year-old) stems from three plants of the Toxicodendron orientale and from the three habitats were analyzed. For each trait, the sample size was 30 measurements. Those values from the three plants were then grouped together to produce one sample of 90 measurements for each trait for the following statistical analysis. An analysis of tissue and cell traits was made for each age group and habitat to calculate the expected value (sample mean), the confidence interval for the expected value. The confidence interval was calculated using the Student's t-distribution (for a $95 \%$ level of confidence). The regression analysis of least squares method was applied to plot age trends of plant. The statistical analysis was conducted with (Min'ko 2004) using the statistical analysis tool in MS Excel. Thus, for the comparative analysis of each bark traits, we use age trends of this trait in the three various habitats. These age trends allow us to assess the velocity of change and to determine the pattern of change in each habitat.

\section{RES U LT S}

The general composition of the bark Toxicodendron orientale has been described (Eryomin \& Kopanina 2012). In the course of the study, we examined a number of samples and made use of the contemporary research methods to describe bark tissues (Angyalossy et al. 2016), thus contributing to the accuracy and completeness of the information available on the bark structure of the Toxicodendron orientale.

The bark of annual stems consists of the following (from the surface of a stem towards its center): the epidermis; the periderm with heterogeneous phellem; the cortex including collenchymatous parenchyma, parenchyma, and secretory cells; groups of possibly protophloem fibers; secretory intercellular canals with epithelial cell; primary phloem; secondary phloem represented by sieve-tubes with companion cells, parenchyma, and secretory intercellular canals (Fig. 2). The epidermis is dying by the end of the first growing season. First periderm is initiated subepidermally 


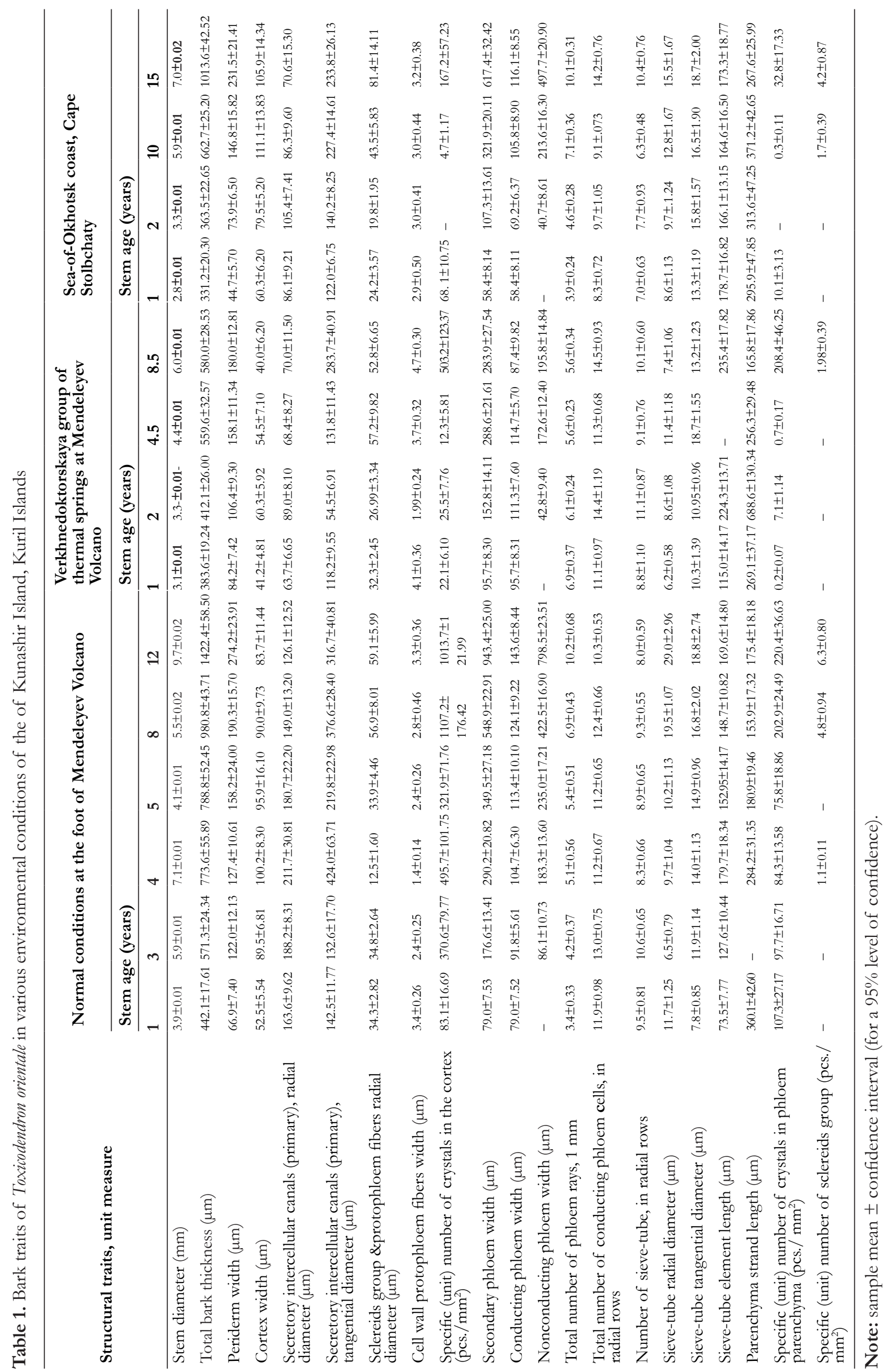


and, by the end of the growing season, contains 4 to 6 layers of phellem and 1 layer of phelloderm. A large proportion of the phellem cells have U-shaped wall thickenings, i.e. the inner tangential wall is thickened together with the adjacent parts of the radial walls (Fig. 2A, B). The arrangement of thin- and thick-walled phellem cells is irregular, with no layering. The secretory cells in the cortex located outside of secretory canals. The groups of secretory cells are large (more than 10 to 15 cells), stretched tangentially, and formed a schizogenous spaces. By the end of the growing season of the first year, those groups frequently get crushed and obliterated (Fig. 2B, C). Mineral inclusions are represented

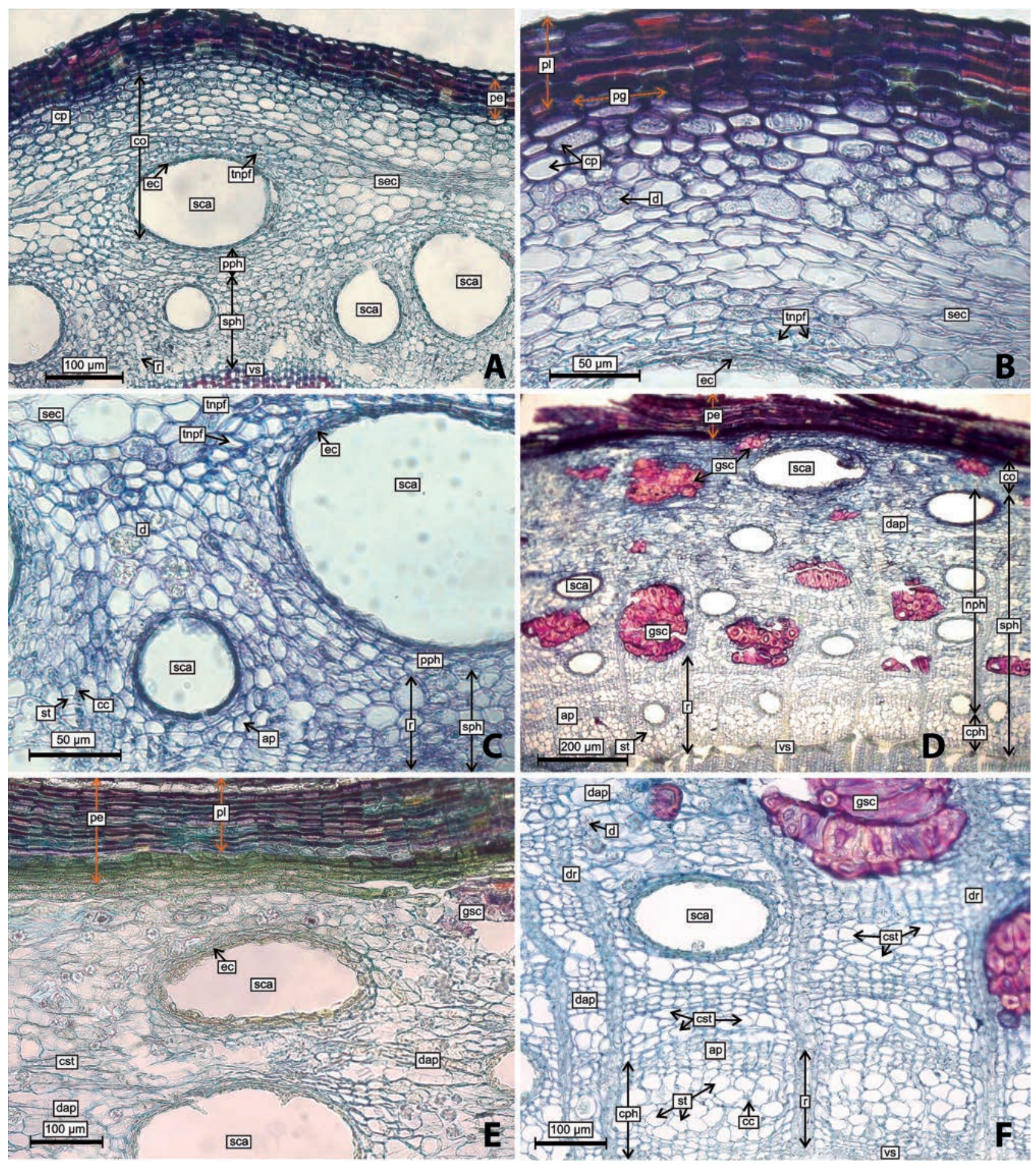

Figure 2 Bark structure of Toxicodendron orientale Greene (Anacardiaceae) under normal environmental conditions. A - bark in annual stem; $\mathrm{B}$ - periderm and cortex in annual stem; C - inner bark in annual stem, phloem; D - bark of perennial mature stem (trunk); E - outer bark of mature stem; F - conducting and nonconducting phloem of mature stem; ap - axial parenchyma, ec - epithelial cell; cc - companion cell; co - cortex; cp - collenchyma-like parenchyma; $\mathrm{cph}$ - conducting phloem; cst - collapsed sieve-tube; $\mathrm{d}$ - druse; dr - dilated ray; dap - dilatated axial parenchyma; gsc - sclereids group; nph - nonconducting phloem; pd - phelloderm; pe - periderm; pg - phellogen; pl - phellem; pph primary phloem; $r$ - ray; sph - secondary phloem; st - sieve-tube; sec - secretory cells; sca - secretory intercellular canals; tnpf - thin-walled protophloem fibers; vs - vascular cambium 
by druses in the parenchyma of the cortex and phloem.

We have previously assumed that one of the diagnostic hallmarks of the Toxicodendron orientale is the presence of thin-walled primary fibers (Eryomin \& Kopanina 2012). Recent evidence refutes this hypothesis. Under different ecological conditions, the annual stems of specimens from the same habitat and even of a single plant contain both thin-walled fibers and fibers with thicker cell walls (with nearly pointlike lumina) (Fig. 2, 3). Primary (protophloem) fibers form 2- to 3-seriate groups that wrap around large primary secretory canals. The fibers groups to not contact, and remain separated by parenchyma cells. The fibers are of different shapes ranging from round to polygonal in cross section, often tangentially elongated. The large secretory intercellular canals (primary) are lined with epithelium and surrounded by accompanying parenchyma.

The conductive elements of the primary phloem are present in an annual stem in a functional state. The sievetube elements form fuzzy clusters of 4 to 7 that are tangentially stretched and scattered throughout the parenchyma. The parenchyma is diffused. The sieve-tube elements of the secondary phloem are grouped into fuzzy clusters, consisting of 3 to 4 or more (5-7) sieve-tubes that are bordered by the cells of diffused axial parenchyma. The sieve plates are simple. The sieve-tube elements are accompanied by solitary companion cells, just like in the primary phloem. In cross section, sieve-tubes are almost square. The structure of the secretory intercellular canals is similar to that of the primary canals. Their size is usually significantly smaller. There are both homocellular rays formed by procumbent cells and heterocellular ones. Uniseriate and, less frequently, 2 - and 3 -seriate rays prevail. The maximum width of phloem rays is 3 cells.

The bark of mature stems consists of outer periderm and all the above-listed tissues with significant modifications (Fig. 2, 3). Primary tissues very often remain in the bark of the Toxicodendron orientale mature stems, expanding by tangential stretching and anticlinal cell division (Fig. 2D, E). The large secretory intercellular canals (primary) deform with age, decreasing radially under the pressure of the building-up nonconducting phloem. The groups of fibers rupture with age, their fibers deforming and getting crushed under the pressure of new tissue layers. Most of the phellem cells have U-shaped cell wall thickenings. There are very rare occurrences of thin-walled cells; they either have a diffused pattern or form a separate layer. Alternating bands
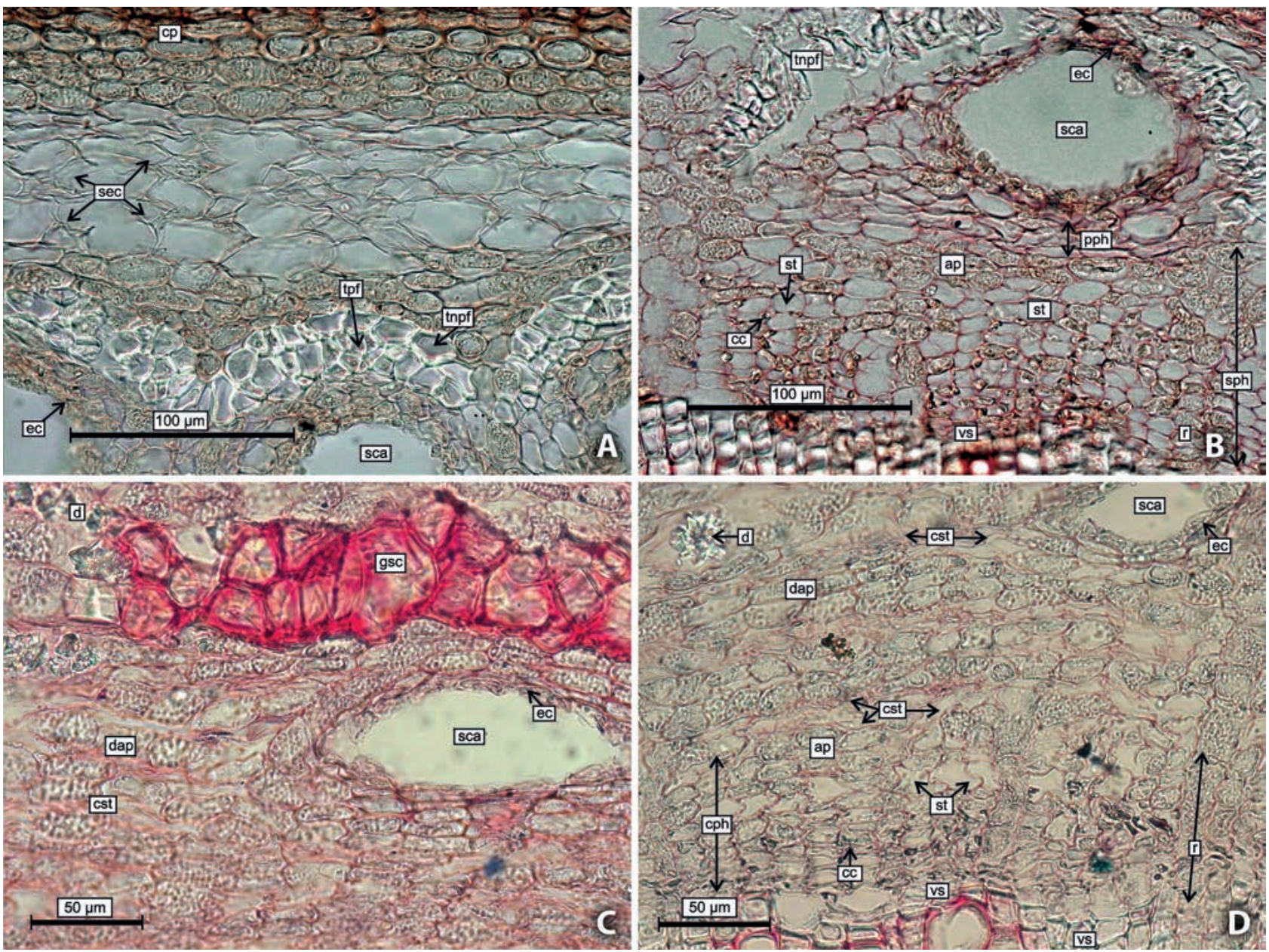

Figure 3 Bark structure of Toxicodendron orientale Greene (Anacardiaceae) under the gas-hydrothermal spring conditions. A - cortex and primary phloem in annual stem; B - inner bark in annual stem, phloem; C - nonconducting phloem of perennial stem; D - conducting and nonconducting phloem of perennial stem; ap - axial parenchyma, ec - epithelial cell; cc - companion cell; co - cortex; cp - collenchyma-like parenchyma; cph - conducting phloem; cst - collapsed sieve-tube; d - druse; dap - dilatated axial parenchyma; gsc - sclereids group; pph primary phloem; $\mathrm{r}$ - ray; sph - secondary phloem; st - sieve-tube; sec - secretory cells; sca - secretory intercellular canals; tpf - thick-walled protophloem fibers; tnpf - thin-walled protophloem fibers; vs - vascular cambium 
of thin- and thick-walled cells may form, with the phellem then assuming a layered structure. The phelloderm is thick (4 to 5 cell layers) and consists of parenchymatous cells. Lenticels are rare. As the layers of the phellem build up, it starts to locally delaminate with scales forming on the stem surface. Subsequent periderms are concentric. The bulk of the bark is made up of nonconducting phloem. No remnants of the primary phloem can be identified (Fig. 2D). Towards the periphery of the bark, the cortex is represented by a dilated primary parenchyma that contains druses and sclereid groups. The sclereid groups are made up of variously shaped brachysclereids.

The growth rings of phloem increments are distinguishable for up to 5 to 6 years on account of the deformity of sieve-tubes, farther into the bark, however, sieve-tubes become almost completely obliterated and the layering behavior of tissue "vanishes" (Fig. 2E). Both axial and ray parenchyma are subject to dilation, yet axial parenchyma is by far the predominant one. Dilation of axial parenchyma is effected by tangential stretching and anticlinal divisions of parenchyma cells. Ray dilation is manifested in a slight cell expansion. Some of the rays, especially uniseriate ones, become tortuous until they "vanish" in the bark without dilating during year 3 or 4 (Fig. 2 F). The rays are narrow, 1 to 3 cells in width. Sclereids are formed from the dilatation parenchyma cells of, primarily, the axial parenchyma in nonconducting phloem and the cortex, and, rarely, the phloem ray in nonconducting phloem and phelloderm. In sclereids, the non-branching pores are fairly pronounced. The lumina of the sclereids are of various (down to pointlike) sizes. The sieve-tubes of the conducting phloem of mature stems are polygonal or rounded polygonal in cross section; they are grouped into clusters of 9 to 25 or more (Fig. 2F). The cell walls of all the sieve-tubes are undulating, their radial and tangential sizes being much larger than those of the axial parenchyma cells. Radially, the large clusters are bounded by rays, and tangentially - by the bands of axial parenchyma of the current and previous annual increments. Sieve-tubes are smaller and square- or rectangular-shaped, witch located at the end of the phloem growth rings. Diffuse parenchyma in the form of individual cells or small groups. The greater part of it is localized to interrupted or continuous bands, 2 to 4 or more cells wide, at the end of each phloem growth rings. The secretory intercellular canals have a structure similar to that of the phloem canals in the bark of an annual stem and are diffused throughout the secondary phloem. No fibers form in the secondary phloem.

Under normal conditions, on account of the annual increment, the width of the bark of a 12-year-old Toxicodendron orientale specimen exceeds that of a annual stem in 3.5 times, and the periderm in 4 times (Table 1). By age 12 , those tissues (bark and periderm) become as width as $1420 \pm 58.5 \mu \mathrm{m}$ and $274 \pm 23.9 \mu \mathrm{m}$, respectively (Fig. 4A). The first periderm works up to $8-10$ years. At an older age, the phellem may build up in some parts of the stem to reach a width of more than 600 to $700 \mu \mathrm{m}$. With age,
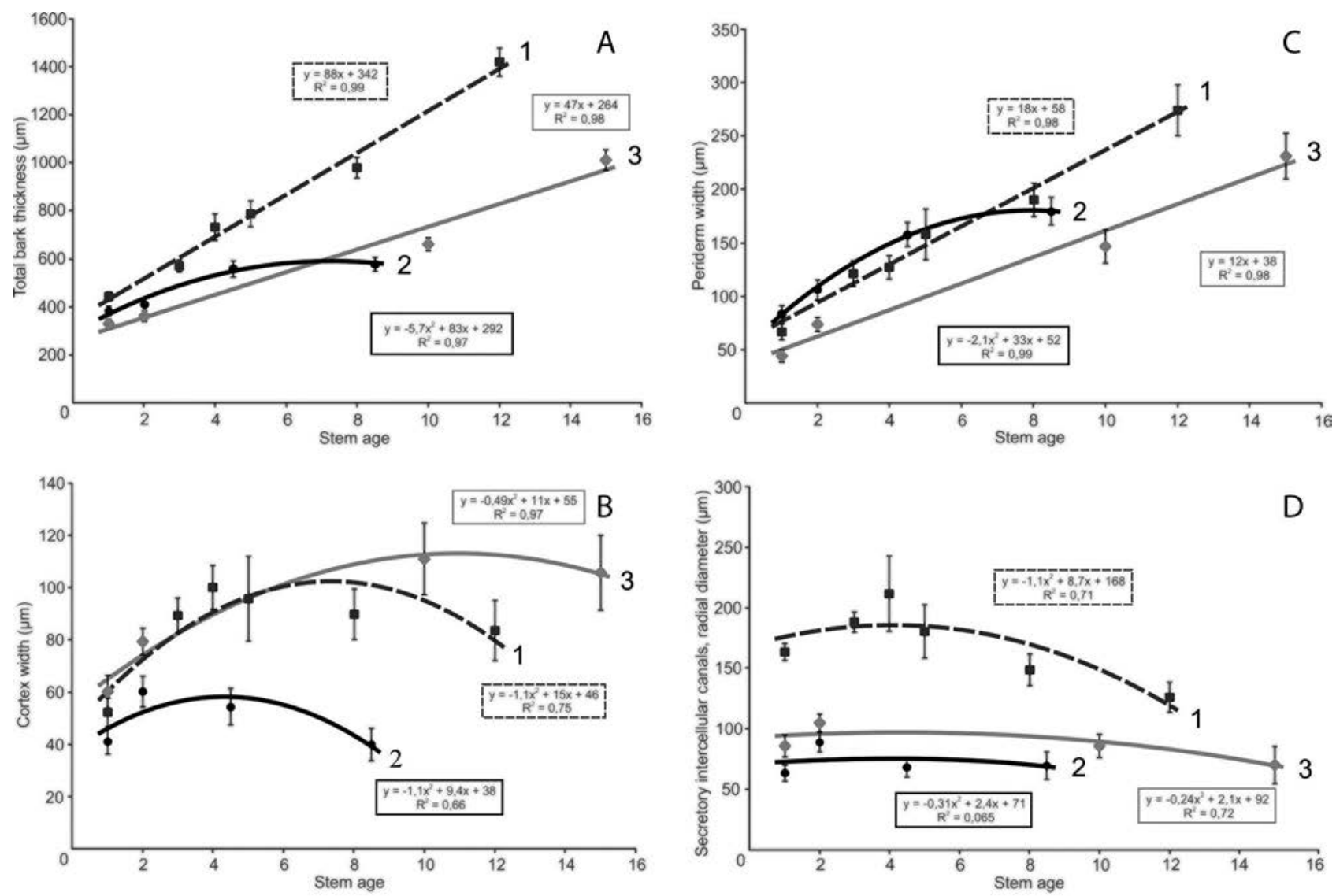

Figure 4 Age trends of the bark width and some traits of primary tissues in Toxicodendron orientale Greene (Anacardiaceae) under different environmental conditions. 1 - normal conditions, 2 - gas-hydrothermal spring , 3 - sea coast; A - total bark thickness (width), $\mu$ m; B - cortex width, $\mu \mathrm{m}$; $\mathrm{C}$ - periderm width, $\mu \mathrm{m}$; D - secretory intercellular canals (primary), radial diameter, $\mu \mathrm{m}$ 
the width of nonconducting phloem also increases linearly yet faster than the other bark traits to become 8 to 9 times greater than that of a one-year stem at age 12 (Fig. 5B). The width of the conducting phloem increases in 2 times to average $144 \pm 8.4 \mu \mathrm{m}$ in a 12 -year stem (Fig. $5 \mathrm{C}$ ). Note that the conducting phloem is consisting for only by the phloem growth ring of the current-year. The total conducting phloem cell number, including numbers of the sieve-tubes in the radial rows, is relatively constant over the years. By age 8 to 10 , the sieve-tube elements assume the shape and size typical of the species under study. Thus, the radial diameter of the sieve-tubes of the stipe becomes nearly 3 times that of a one-year stem, and the tangential diameter -2 times that (Table 1, Fig. 6). With age, the sieve-tubes also take definite shape to become polygonal and rounded polygonal in cross section, the axial parenchyma becomes regular in arrangement, and the number of phloem rays per $1 \mathrm{~mm}$ of cross section increases linearly to reach an average of $10.2 \pm 0.68$ rays per $1 \mathrm{~mm}$ by age 12 (Table 1 , Fig. 5 ), and the proportion of 3-and 4-seriate heterocellular rays goes up.

Under extreme conditions, i.e. by gas-hydrothermal springs and on the seashore, the basic bark traits of the Toxicodendron orientale described various age-trends. On the seashore, young stems have thin bark (Table 1). Under normal condition the bark width is the highest values. Inverse regularity hold true for the periderm and, specifically, the phellem: these bark tissue are the widest in plants from around gas-hydrothermal springs. On the seashore, the age- phellem width relationship is similar to that under normal conditions yet with smaller width values. By 8 to 9 years of age, the total width of the bark and that of the external protective tissues decrease to become thinner than under normal conditions (Table 1, Fig. 4).

The number of crystals in the bark cells is one of the characteristics that are sensitive to changes in the environments of their habitats. It has been observed that as the habitat conditions deteriorate, this trait increases (Eryomin \& Kopanina 2012). For the Toxicodendron orientale, an analysis of the specific (unit) number of crystals in the cortex and the secondary phloem in the bark ontogenesis, as well as under a range of ecological conditions, has shown the following. Under normal conditions, this trait increases unevenly with age. Around the gas-hydrothermal springs and on the seashore, the number of crystals is much less, especially so in young stems.

We have noted above that the degree of secondary sclerification in the parenchymal tissues of the Toxicodendron orientale is low under normal conditions - rare groups of sclereids and individual sclereids occur at age 4 with the specific number of sclereid groups in the nonconducting phloem reaching $6.3 \pm 0.80$ per sq. $\mathrm{mm}$ by 12 years of age (Table 1). Around the gas-hydrothermal springs, however, the specific number of sclereid groups is more than twice as low at only $2.0 \pm 0.39$ per sq. $\mathrm{mm}$.

Lianas growing near thermal springs demonstrate atypical changes of nonconducting and conducting phloem
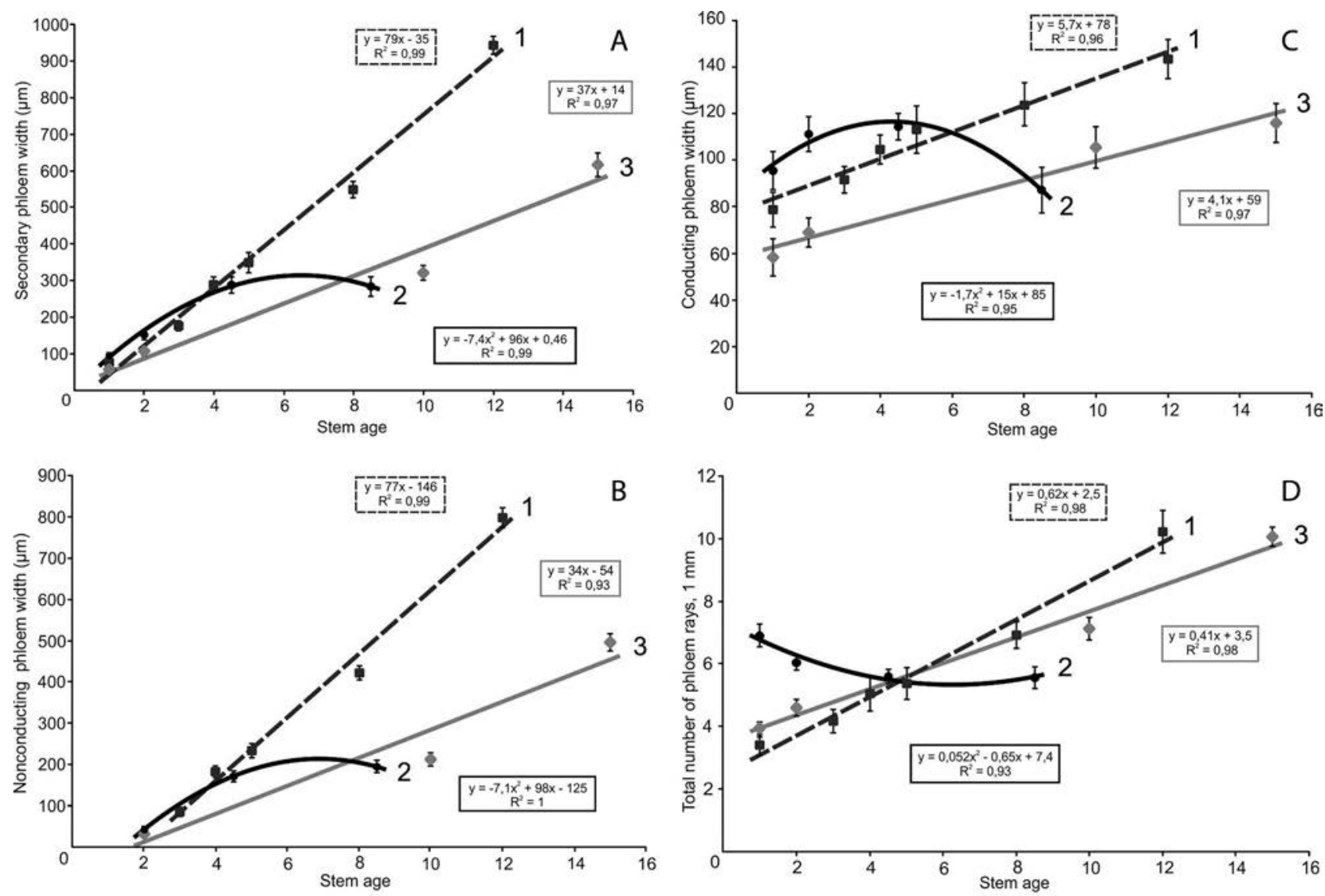

Figure 5 Age trends of some traits of the secondary phloem in Toxicodendron orientale Greene (Anacardiaceae) under different environmental conditions. 1 - normal conditions, 2 - gas-hydrothermal spring, 3 - sea coast; A - secondary phloem width, $\mu \mathrm{m}$; B - nonconducting phloem width, $\mu \mathrm{m}$; $\mathrm{C}$ - conducting phloem width, $\mu \mathrm{m}$; D - number of phloem rays, $1 \mathrm{~mm}$ 
width (Fig. 5). Under normal conditions, those traits of the Toxicodendron orientale change linearly with age. The same trend for change of those traits has been identified in the plants growing on the seashore. Near the gas-hydrothermal springs, the width of the conducting and nonconducting phloem of young (4 to 5-year-old) stems is greater than under normal conditions. With age, those values go down to become the lowest relative to the norm and the seashore conditions by 8 to 9 years of age.

Near the gas-hydrothermal springs, the radial and tangential diameters of the sieve-tubes in the young stems increase with age (Fig. 6). These parameters are slightly decreased by 8-10 years. With comparable sizes around the gas-hydrothermal springs, the sieve-tubes are nearly rectangular-shaped in cross section throughout the ontogenesis of the stem. A similar change in the shape of the sieve-tubes occurs under the seashore conditions (Table 1, Fig. 6). The length of the sieve-tube elements of the Toxicodendron orientale normally increases with age from an average $73.5 \pm 7.77 \mu \mathrm{m}$ during the first year to $179.7 \pm 18.34 \mu \mathrm{m}$ during year 4 to undergo almost no further change (Table 1, Fig. 6, 6D). Near the gas-hydrothermal springs, the sieve-tube elements of all ages are nearly twice as long as their counterparts under normal conditions. In seashore environments, their values are close throughout the ontogenesis.

The type and structure of the phloem rays of the Toxicodendron orientale undergo no change in different environ- ments. At the same time, the total number of phloem rays per $1 \mathrm{~mm}$ of cross section increases with age under normal and seashore conditions (Fig. 6). It should be noted that this trait is more than twice as high in the young stems from around gas-hydrothermal springs than in any other environments surveyed. Near the gas-hydrothermal springs, however, the number of phloem rays goes down with age to hit the lowest value among all the samples examined by year 8 to 9 .

The cortex and the secretory intercellular canals (primary) do not contribute significantly to the width of the definitive bark of the stems, as they deform under the pressure of the underlying tissues (Fig. 4D).

\section{DISCUSSION}

The analysis of the findings distinguishes a number of specific features in the bark structure of the Toxicodendron orientale, which depend on the ecological conditions and, specifically, the influence of the gas-hydrothermal activity of the volcanoes. The identified trend for decrease in the bark increment of liana stems from around the gas-hydrothermal springs and the seashore is evidently a typical reaction to stress conditions and is caused by the reduced volume of plastic material and the corresponding internal rearrangements of the functional organization of a plant. However, in some years (during the first years of ontogenesis), the bark width is close to that under normal
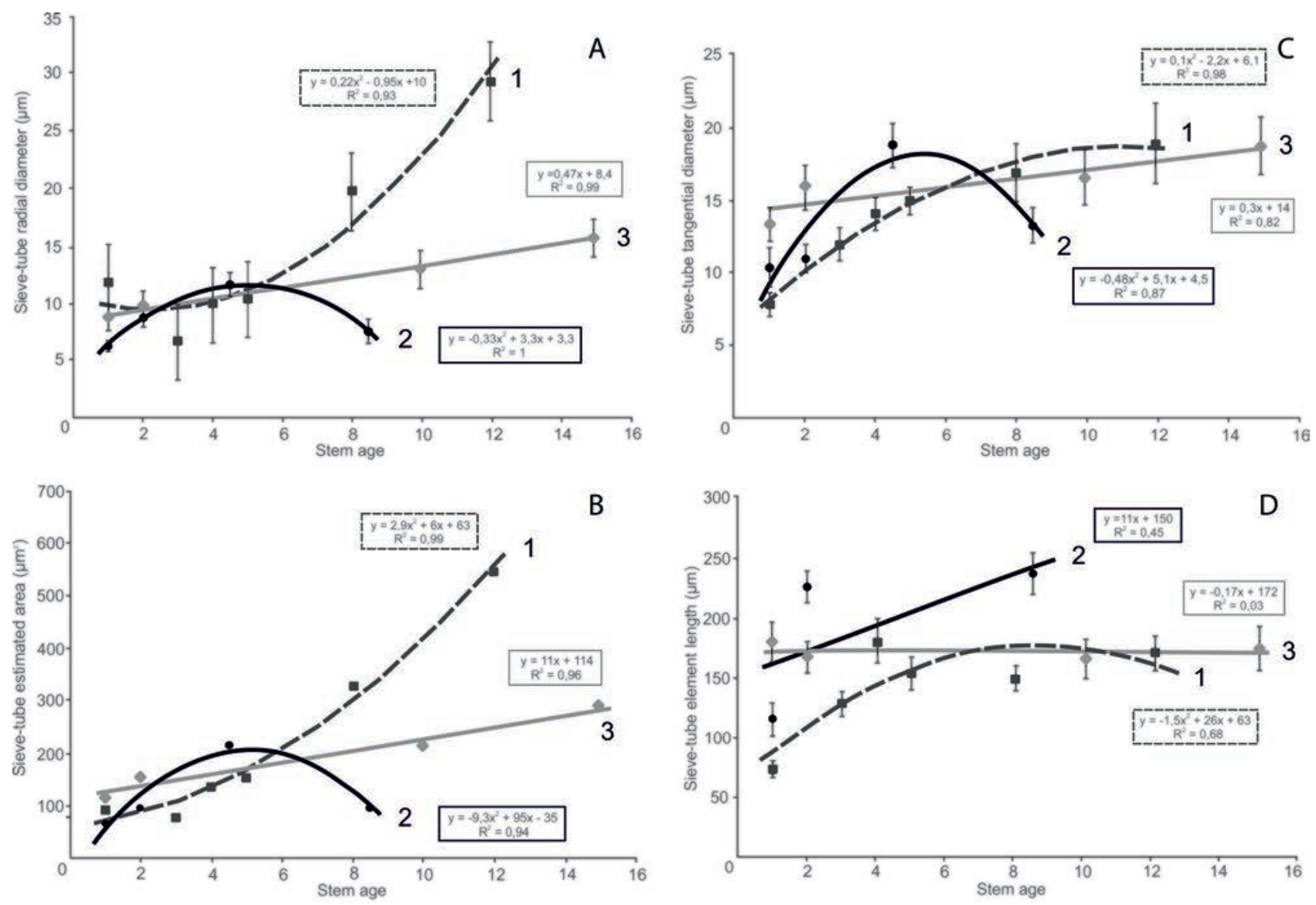

Figure 6 Age trends of sieve-tube elements of the conducting phloem in Toxicodendron orientale Greene (Anacardiaceae) under different environmental conditions. 1 - normal conditions, 2 - gas-hydrothermal spring, 3 - sea coast; A - sieve-tube radial diameter, $\mu$ m; B - sievetube tangential diameter, $\mu \mathrm{m}$; $\mathrm{C}$ - sieve-tube estimated area, $\mu \mathrm{m}^{2}$; D sieve-tube element length, $\mu \mathrm{m}$ 
conditions whereas the width of the periderm and the phellem is even more than normal. Decrease the bark width in conditions of gas-hydrothermal springs of Mendeleev volcano are the results for some Vaccinium L. (Ericaceae) (Eryomin \& Kopanina 2012), Spiraea beauverdiana Schneid. (Rosaceae) (Kopanina et al. 2017, Kopanina 2019). Decrease the bark width, the growth rings in the secondary phloem, has been studied for Pinus sylvesris and Betula pendula under conditions of long-standing air pollution by industrial emissions (e.g. Stasova et al. 2009, 2011).

We should bring to your attention the papers (Pausas 2015, Schafer et al. 2015, Richardson et al. 2015), that deal with the relationship between the bark thickness (width) and the ecological conditions of the habitats of woody plants. It is obvious that the extent of thermal insulation and protection of the vital tissues in the stem of a woody plant depends on the bark width (especially the outer bark, represented by periderm or rhytidome). Therefore, the development of thick tree bark can be considered as a mechanism of protection against infections, herbivorous animals, extreme climatic conditions (frost, extreme cold, extreme temperatures, drought, etc.), or fire (Pausas 2015). Recent studies have shown that in ecosystems where fires do not exert evolutionary pressure, there can be encountered very thin bark (rainforest) with a very high variability of this parameter. This is probably due to protection against water stress or vermin (Richardson et al. 2015). There is no clarity yet as to the dependence of bark width on environmental factors. We agree with the conclusions of Pausas (2015) and Richardson et al. (2015) regarding the need to accumulate more data on bark thickness, thus expanding the range of investigated species and life forms.

We assume that near the gas-hydrothermal springs the thick layer of the phellem (is even more than normal) determines the enhanced protective function of the young stems and can also serve as a depository for metabolites. Given the slightly increased rate of periderm build-up near the gas-hydrothermal springs, the reduction in the width of this tissue in subsequent years may be caused by the active shedding of the external layers.

The age-related change the cortex width and the diameter of the secretory intercellular canals (primary), which normally reduce due to the decreased functional relevance thereof and dilation, occurs similarly under extreme conditions. This being the case, the minimum values of those traits at all ages surveyed are observed in the plants from around the gas-hydrothermal springs.

The bark sclerification and the accumulation of mineral inclusions (calcium oxalate crystals) in the bark tend to intensify with age due to the deposition of excess metabolites. As for the Toxicodendron orientale, this trend has been found in the plants growing under normal conditions. The dependence of those indicators on environmental factors in a deep structural and functional sense has been revealed by studies of the structural anomalies in the bark and wood tissues of Karelian birch (Novitskaya 2008). A special combination of abiotic factors, specifically high solar exposure and soil poverty, lead to the formation of a significant amount of photosynthetic products in Karelian birch; primarily, to an increased sucrose concentration, which has a trigger effect. In structural terms, this leads to increased parenchymatization of bark tissues and, with age, to sclerification thereof. One peculiar feature identified in the Toxicodendron orientale - the reduction in the specific content of sclerified parenchyma and crystalline inclusions in the bark from around the gas-hydrothermal springs and the seashore - can probably be accounted for by the lack of plastic substances in plants growing under extreme conditions. This fact testifies to the slowing down of calcium oxalate excretion and, possibly, to the crystals getting involved in metabolism under those conditions.

The main structural deviations from normal growth in the bark of the Toxicodendron orientale have been found in the secondary phloem and, for the most part, in the conducting phloem. Near the gas-hydrothermal springs, the conducting and nonconducting phloem width of young (4 to 5-yearold) stems is increasing and in mater stems, is decreasing than under normal conditions. The number of conducting phloem elements (in radial rows) produced by cambia has close values in all habitats (Table 1). Therefore, the inversion of the conducting phloem width in the conditions of gas-hydrothermal springs is connected with small cells of phloem and sieve-tubes.

According to some publications, the shape of the sievetubes in cross section is one of the attributes which might be of diagnostic significance for Rosaceae (Lotova \& Timonin 2005). Under normal conditions, the radial diameter of the sieve-tubes of Toxicodendron orientale increases with age whereas the tangential diameter decreases, i.e. become rounded in cross section, get generally larger, and assume a stable shape (large rounded, polygonal ones and small square, rectangular ones) by 8 to 10 years of age. Besides, with age, the arrangement of sieve-tubes in clusters becomes more regular; and the sieve-tubes get larger. Thus, according to our data on the Toxicodendron orientale, the diagnostic value of the shape of the sieve-tubes in cross section is minimal because it depends on the age of the stem and on environmental conditions.

An analysis of our data has revealed trends for the conducting phloem of the Toxicodendron orientale: 1) an increase diameter, estimated area and length of a sieve-tube elements during ontogenesis; 2) an decrease diameter and estimated area of a sieve-tube elements under extreme conditions; 3) an increase length of a sieve-tube elements the sieve-tube elements near the gas-hydrothermal springs; 4) adult plants retain a diffused, weakly regular arrangement of sieve-tubes of the conducting phloem (they do not form well-defined small clusters or groups, or are diffuse) near the gas-hydrothermal springs; 5) an increase a number of uniseriate rays near the gas-hydrothermal springs.

Our findings on the wide and long sieve-tube elements in the definitive bark of the Toxicodendron orientale are consistent with the data presented by other researchers on the conducting phloem of other lianas. Wide conductive structures of lianas were first described in the secondary xylem. Today, according to numerous studies, we are aware that lianas specialize in increasing the conductivity of the secondary xylem thanks to very wide vessel members, as we 
know lianas to require an additional water supply to compensate for any losses caused by the high transpiration of their large canopies (Ewers \& Fisher 1991, Angyalossy et al. 2012). For a related species - Toxicodendron diversilobum (Torr. \& A. Gray) Greene, it has been demonstrated that the differences in mechanical properties of stems of the shrubby form and those of the liana form are mainly caused by differences in stem geometry (Gartner 1991). During the juvenile and self-supporting forms, the xylem generally includes narrow and scarce vessels, thick fibres, and nearly no axial parenchyma (Angyalossy et al. 2012).

Structural features which can be described as specialization of lianas over time recorded have been identified in the tropical lianas (Bignoniaceae): the regular and variant phloem types; the increase in sieve-tube area in the variant phloem; increase in the abundance of phloem parenchyma for the regular phloem (Pace et al. 2011). It's very important that wider sieve-tubes in the variant phloem likely contributed to an increase in the importance of the variant phloem in conduction of photosynthates, while the increased abundance of parenchyma likely enhanced the storage capacity of the regular phloem. An increased conductance role for the phloem with large and round sievetube elements provides an additional significance for the evolution lianas (Pace et al. 2011, Angyalossy et al. 2012). And we observe similar changes in the sieve-tubes of Toxicodendron orientale: the increase in sieve-tubes diameter and area (larger and round sieve-tube elements in the mature stem) in ontogenesis and in the conditions of the volcano. This also probably increased the conduction of photosynthesis.

The studies of the secondary xylem of the tropic lianas have demonstrated that, besides being wide, the liana vessel members are also long (Fisher \& Ewers 1989) according to (Angyalossy et al. 2012), as they enable efficient transport for water and nutrients in the long and narrow stems. The correlation between the geometric characteristics of the sieve-tube and its conductivity is shown (Mullendore et al. 2010). The increase in sieve-tube element length (in Phyllostachys nuda McClure.) is accompanied by an increased influence on sieve-tube conductivity (Mullendore et al 2010). With age and in the conditions of the volcano, over the course of establishment of the liana form of Toxicodendron orientale, the length of the sieve-tube elements increases. Unfortunately, there is (Angyalossy et al. 2012) no information regarding the length of the sieve-tube elements in the papers under discussion. Bearing in mind the fact that the emergence in lianas of wide conductive elements in the xylem and phloem sets the vascular system of this liana form (examples from the Bignoniaceae and Leguminosae, the two most abundant liana taxa in the Neotropics) (Angyalossy et al. 2012), we believe that the length of the sieve-tube elements is yet another such distinguishing feature of this liana form. We are also aware that this is just an assumption that traits close scrutiny for various types of lianas.

Our findings show that the Toxicodendron orientale exhibits a correlation between the formative process in the ontogenesis of the liana and the anatomical features of the conductive system, specifically the phloem. Among those signs that distinguish a climbing stem attached to a support are the increased diameter and length of the sieve-tube elements, the formation of clusters thereof contiguous with the axial and ray parenchyma, and the increased volume of the phloem parenchyma. Thus, the large and long sievetubes and the parenchymatization of the phloem may serve as additional specialization in lianas.

For lianas in Bignonieae (Bignoniaceae), the maintenance of narrow rays inside the variant phloem in an adult plant is shown and is a case of true paedomorphosis in the secondary phloem (Pace et al. 2009). The age trend demonstrated by the structural features of the conducting phloem in the Toxicodendron orientale and identified during the study (the diffuse arrangement of the sieve-tubes and the prevalence of uniseriate rays in the adult plants) near the gas-hydrothermal springs, may be regarded as retention of the juvenile traits in the secondary phloem, or pedomorphosis. We're following assumptions about paedomorphosis (Pace et al. 2009, 2011) in the secondary phloem for Toxicodendron orientale.

The duration of the functional state of the sieve-tubes is yet another important attribute of lianas. In this study, noting a very slight deformity (bending) of the cell walls of the sieve-tube elements of the next annual phloem increment, we have assumed that the conducting phloem corresponds to an annual increment of one growing season only. Studies of the recent years (Pace et al. 2011, 2015) have shown an extension of sieve-tube functioning time of up to several years in many lianas. It can therefore be assumed that the sieve-tubes of the Toxicodendron orientale conduct assimilates for 2 or more years. This assumption needs to be clarified and further explored.

Thus, the Toxicodendron orientale has revealed some significant differences in the structural organization of its bark and the annual and mature stem bark tissues that constitute it under various ecological conditions. We believe those differences to be based on the different physiological roles of the tissues of the juvenile and definitive barks. Those agespecific structural and physiological features account for the different reactions of the bark tissues to the environmental factors of specific habitats, as has also been identified during our study. In this regards, our findings are in some way consistent with the trunk and branch bark data for 85 angiosperm species from six habitats with contrasting precipitation and temperature modes and fire situations (Rosell et al. 2015). The authors have shown (Rosell et al. 2015) that the trunk bark is from the ecological standpoint much more than just a "thicker version" of the bark of annual and perennial branches.

\section{CONCLUSION}

A detailed analysis of the bark tissue traits of the woody liana Toxicodendron orientale under various environmental conditions at ages 1 to 15 has revealed the formation pace and stages of the bark structures, and the special aspects of age-related transformations of tissues and their elements under normal and extreme conditions. We have found that the Toxicodendron orientale exhibits a correlation between the formative process in the ontogenesis of the liana and the 
anatomical attributes of the secondary phloem. Among those signs that distinguish a climbing shoot attached to a support are the increased diameter and length of the sievetube elements, the formation of clusters thereof contiguous with the axial and ray parenchyma, and the increased volume of the phloem parenchyma.

A number of structural features which characterize the juvenile and definitive traits of the conducting phloem of the Toxicodendron orientale have been established. Under normal conditions, sieve-tubes become rounded in cross section, get larger, and assume a stable form with age (large rounder, polygonal ones and small square, rectangular ones), their arrangement in clusters becomes more regular, and the proportion of multeseriate rays increases by 8 to 10 years of age. The age-specific transformations of the rest of the bark tissues are rather typical: dilation of the cortex parenchyma and the nonconducting phloem, sclerification of the parenchyma with isolated sclereid groups forming, obliteration of sieve-tubes etc.

In the liana bark tissues, there forms a structural response to a combination of extreme conditions, particularly the specific conditions of the gas-hydrothermal springs at the Mendeleyev Volcano on Kunashir Island - high temperatures in the rooting range; hot steam saturated with sulfur oxides; scattered sunlight; and high concentrations of rare-earth and heavy metals in the soil. We assume that the Toxicodendron orientale dwelling near the volcano's gas-hydrothermal springs is low on metabolites and plastic substances and therefore has to engage all its reserves in metabolism. It may be achieved, among other things, by reduction in the bark width and in the number of crystals and sclereids in the parenchymal bark tissues. This is likely to be still insufficient for the normalization of primarily the transport flows, resulting in the pace of plant development slowing significantly down with age. Despite the higher values of the key metrics of bark tissues at a young age (the width of the conducting phloem, the number of phloem rays, and the width of the periderm and phellem), the mater stem of the examined lianas are thin and weak. Plants from near the gas-hydrothermal springs feature a specific course of age trends of bark traits. There is the inversion of main structural traits of the bark. The diversified changes of the structural traits of bark to the action of environmental factors that have been identified during the study suggest that further studies should be conducted, and a greater volume of bark data should be accumulated.

The structural changes of Toxicodendron orientale to extreme conditions near gas-hydrothermal springs are mainly related to the conducting phloem. Comparative analysis of the functional features of this tissue shows the following important trends for plants under extreme volcanic conditions: an inversion some of traits of the bark (bark thickness, secondary and conducting phloem width, total number of phloem rays, diameter and area of the sievetubes elements in the conducting phloem); a decrease of diameter and increase of length of the sieve-tubes elements in the conducting phloem; a diffuse arrangement of sievetubes in the conducting phloem in mature plants and also; a significant amount of the uniseriate rays.
A combination of the harsh seashore conditions is also reflected in the bark structure of the Toxicodendron orientale. This is manifested in a reduction in the main bark tissue traits with the linear pattern of age trends remaining the same. Such changes, however, are not so significant as those around the gas-hydrothermal springs.

Some significant differences have been revealed in the structural organization of bark and the annual stem and stipe bark tissues that constitute it under various ecological conditions. We believe those differences to be based on the different physiological roles of the tissues of the juvenile and definitive barks. Those age-specific structural and physiological features account for the different reactions of the bark tissues to the environmental factors of specific habitats, as has also been identified during our study.

\section{ACKNOWLEDGEMENTS}

The work was supported by the Russian Foundation for Basic Research (07-04-00881, 15-04-04774) and as part of the state assignment of the IMGG FEB RAS.

\section{LITERATURE CITED}

Alves, E.S. \& V. Angyalossy-Alfonso 2000. Ecological trends in the wood anatomy of some Brazilian species. 1. Growth rings and vessels. LAWA Journal 21(1):3-30.

Alves, E.S. \& V. Angyalossy-Alfonso 2002. Ecological trends in the wood anatomy of some Brazilian species. 2. Axial parenchyma, rays and fibres. IAWA Journal 23(4):391-418.

Angyalossy, V., G. Angelesb, M.R. Pace, A.C. Limaa, C.L. Dias-Lemed, L.G. Lohmanna \& C. Madero-Vegab 2012. An overview on the anatomy, development and evolution of the vascular sys-tem of lianas. Plant Ecology \& Diversity 5(2):167-182.

Angyalossy, V., M.R. Pace, R.F. Evert, C.R. Marcati, A.A. Oskolski, T. Terrazas, E. Kotina, F. Lens, S.C. Mazzoni-Viveiros, G. Angeles, S.R. Machado, A. Crivellaro, K.S. Rao, L. Junikka, N. Nikolaeva \& P. Baas 2016. IAWA list of microscopic bark features. IAW A Journal 37(4):517-615.

Barykina, R.P., T.D. Veselova, A.G. Devyatov, H.H. Dzhalilova, G.M. Ilina \& N.V. Chubatova 2004. Handbook of botanical micro-technology. Foundations and methods. Moscow, 312 pp. (in Russian). [Барыкина Р.П., Веселова Т.А., Аевятов А.Г., Ажалилова Х.Х., Ильина Г.М., Чубатова Н.В. 2004. Справочник по ботанической микротехнике. Основы и методы. М. 312 с.].

Bortnikova, S.B., E.L. Bessonova, M.L. Gora, A.L. Shevko, G.L. Panin, I.L. El'tsov, R.E. Zharkov, T.A. Kotenko, S.L. Bortnikova, Yu.A. Manshtein, L.V. Kotenko, D.L. Kozlov, L.A. Abrosimova, Yu.G. Karin, E.V. Lospeeva \& A.Yu. Kazanskii 2013. Gas-hydrothermal active volcanoes of Kamchatke and the Kuril Islands: composition, structure, genesis. Novosibirsk, 282 pp. (in Russian). [Борт-

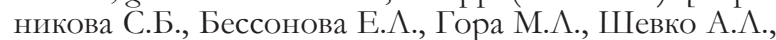
Панин Г.А., ЕАьцов И.А., Жарков Р.Е., Котенко Т.А., Бортникова С.А., Манштейн Ю.А., Котенко А.В., Козцов А.А., Абросимова А.А., Карин Ю.Г., Аоспеева Е.В., Казанский А.Ю. 2013. Газогидротермы активных вулканов Камчатки и Курильских островов: состав, строение, генезис. Новосибирск. 282 с.].

Corothie, H. 1960. Wood anatomy of six genera of Anacardiaceae. Revista Forestal Venezolana 3(3/4):9-31.

Das, D.K. 1984. Wood anatomy of some timbers of Ana- 
cardiaceae of Bangladesh. Wood Anatomy Series, Forest Research Institute (Chittagong) (8):i+31+9pl.

De Mattos Filho, A. 1990. Taxonomy and wood anatomy of Apterokarpos gardneri and Loxopterygium sagotii (Anacardiaceae). Revista Brasileira De Biologia 50(2):433-442.

Dong, Zh. \& P. Baas 1993. Wood anatomy of trees and shrubs from China. 5. Anacardiaceae. IAWA Journal 14(1):87-102.

Eryomenko, N.A. \& V.Yu. Barkalov 2009. Seasonal development of plants of the southern Kuril Islands. Dal'nauka, Vladivostok, 280 pp. (in Russian). [Ерёменко Н.А., Баркалов В.Ю. 2009. Сезонное развитие Южных Курильских островов. ВАадивосток: Аальнаука. 280 с.].

Eryomin, V.M. \& A.V. Kopanina 2012. Atlas of the bark anatomy of trees, shrubs and lianas of Sakhalin and the Kuril Islands. Brest, 896 pp. (in Russian). [Ерёмин B.M., Копанина А.В. 2012. Атлас анатомии коры деревьев, кустарников и миан Сахалина и Курильских островов. Брест. 896 с.].

Ewers, F.W. \& J.B. Fisher 1991. Why vines have narrow stems: Histological trends in Bauhinia (Fabaceae).Oecologia 88:233-237.

Fisher, J.B. \& F.W. Ewers 1989. Wound healing in stems of lianas after twisting and girdling injuries. Botanical Gazette 150:251-265.

Gartner, B.L. 1991. Structural stability and architecture of vines, shrubs of poison oak. Ecology 72(6):2005-2015.

Gibson, A.C. 1981. Vegetative anatomy of Pachycormus (Anacardiaceae). Botanical Journal of the Linnean Society 83(4):273-284.

Gimenez, A.M. \& G. Moglia 1995. Bark structure of Argentine species of Anacardiaceae. Investigasión Agraria: Sisemas y Recursos Forestales 4(2):189-203.

Gladkova, G.A \& G.K. Butovets 1988. Volcanic soils of Kunashir Island. Pochvovedenie 2:54-67 (in Russian). [T кова Г.А., Бутовец Г.К. 1988. Вулканические почвы острова Кунашир / / Почвоведение. № 2. С. 54-67].

Gomez, C.L. 2009. Anatomy of the wood and bark of Attilaea abalak. E. Martinez and Ramos, gen. and sp. nov. (Anacardiaceae). Acta Botanica Hungarica 51(1/2):75-83.

Gupta, S. \& M. Agarwal 2008. Wood anatomy of Anacardiaceae from India with special reference to systematic position of Rhus. LAWA Journal 29(1):79-106.

Kopanina, A.V. \& V.M. Eryomin 2011. Structural features of the bark of some bushes and shrubs under the conditions of hydrothermal activity of Kunashir Island volcanoes (Southern Kurile Islands). In: Materialy mezhdunarodnoi konferentsii "Strukturnye I funktsionalnye otkloneniya ot normalnogo rosta $i$ razvitiya rastenii pod vozdeistviem factorov sredy", (L.L. Novitskaya, ed.), pp. 127-131, Karel'skii Nauchnyi Tsentr Rossiiskoi akademii nauk, Petrozavodsk (in Russian). [Копанина A.B., Epeмин B.M. 2011. Структурные особенности коры некоторых кустарников и кустарничков в условиях гилротермальной активности вулканов острова Кунашир(Южные Курильские острова) / / Материалы межАународной конференции «Структурные и функциональные отклонения от нормального роста и развития растений под воздействием факторов среды» / под реА. А.А. Новицкой. Петрозаводск: КарНЦ РАН. C. 127-131]

Kopanina, A.V., I.I. Vlasova \& V.M. Eremin 2015. Structural adaptation of woody vine Toxicodendron orientale
Greene in a gas-hydrothermal spring Mendeleev volcano (Kunashir Island, Southern Kuriles). In: Tezisy dokladov V serossiiskoi konferencii s mezhdunarodnym uchastiem I shkoly dlya molodyh uchyonih "VIII s"ead obshchestva fiziologov rastenii Rossii. Rasteniya v usloviyah global'nyh $i$ lokal'nyh prirodnoklimaticheskih I antropogennyh vozdeistviì), (A.F. Titov, ed.), pp. 273, Karel'skii Nauchnyi Tsentr Rossiiskoi akademii nauk, Petrozavodsk (in Russian). [Копанина A.B., Вıасова И.И., Еремин В.М. 2015. Структурные аАаптации

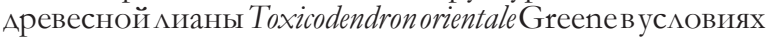
газогилротерм вулкана Менделеева (о-в Кунашир, Южные Курильские острова) // Тезисы докладов Всероссийской конференции с международным участием и школы Аля молодых ученых «VIII съезА общества физиологов растений России. Растения в условиях глобальных и мокальных природно-климатических и антропогенных воздействий» / поА реА. А.Ф. Титова. Петрозаводск:КарНЦ РАН. С. 273].

Kopanina, A.V., Vlasova, I.I., Vatserionova, E.O. 2017. Structural adaptation of woody plants to the conditions of volcanic landscapes of the Kuril Islands. Vestnik Dal'nevostochnogo Otdeleniya Rossiiskoi Academii Nauk 1: 88-96 (in Russian). [Копанина А.В., В масова И.И., Вацерионова Е.О. Структурные адаптации древесных растений к условиям вулканических мандшафтов Курильских островов // Вестник Аальневосточного отАеления Российской академии наук. № 1. С. 88-96].

Kopanina, A.V. 2019a. Structural features of bark and wood of Spiraea beauverdiana (Rosaceae) in the extreme conditions of Arctic and volcanic activity on the Kuril Islands. Sibirskii Lesnoi Zurnal 3:52-63 (in Russian). [Копанина А.В. 2019. Структурные особенности коры и Аревесины Spiraea beawerdiana (Rosaceae) в экстремальных условиях Арктики и поствулканической активности на Курильских островах // Сибирский месной журнал. 3:52-63].

Kopanina A.V. 2019b. Woody plants in the environments of active volcanoes of Sakhalin and Kuril Islands: structural changes of bark tissues. In: Plant anatomy: traditions and perspectives. Materials of the International Symposium dedicated to the 90th anniversary of Prof. Ludmila Ivanovna Lotova, vol. 1, pp. 128-129, MAKS Press, Moscow.

Lotova, L.I. \& A.K. Timonin 2005. Anatomy of a bark of Rosales: diversity, evolution, taxonomic significance. Tovarishchestvo nauchnykh izdaniy KMK, Moscow, 264 pp. (in Russian). [Аотова А.И., Тимонин А.К. 2005. Анатомия коры розоцветных: разнообразие, эволюция, таксономическое значение. М: Товарищество научных изданий KMK. 264 c.].

Min'ko, A.A. 2004. Statistical analysis in MS Excel. Dialektika, Moscow, 448 pp. (in Russian). [Минько А.А. 2004. Статистический анализ в MS Excel. M: Аиалектика. 448 c.].

Meng, Zh., W. Shuonan \& H. Zhenghai 2012. Structure and development of phloem in Toxicodendron vernicifluum. Scientia, Silvae, Sinicie. Plate I-III 48(9):36-41 (in Chinese).

Mullendore, D.L., C.W. Windt, H. Van As \& M. Knoblaucha 2010. Sieve tube geometry in relation to phloem flow. Plant Cell 22:579-593.

Nedoluzhko, V.A. 1995. Anacardiaceae. In: Vascular plants of Soviet Far East, vol. 7 (S.S. Kharkevich, ed.), pp. 247-249, Nauka, Saint-Petersburg (in Russian). [Недолужко B.A. 1995. Фисташковые (Anacardiaceae). Сосудистые растения Советского Аальнего Востока / отв. ред. С.С. Харкевич. Санкт-Петербург: Наука. Т. 7. С. 247-249].

Novitskaya, L.L. 2008. Karelian birch: mechanisms of growth and development of structural anomalies. Verso, Petrozavodsk, 144 


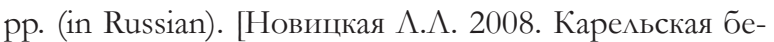
реза: механизмы роста и развития структурных аномалий. Петрозаводск: Verso. 144 с.].

Pace, M.R., S. Alcantara, L.G. Lohmann \& V. Angyalossy 2015. Secondary phloem diversity and evolution in Bignonieae (Bignoniaceae). Annals of Botany 116:333-358.

Pace, M.R., L.G. Lohmann \& V. Angyalossy 2011. Evolution of disparity between the regular and variant phloem in Bignonieae (Bignoniaceae). American Journal of Botany 98(4): 602-618.

Pausas, J.G. 2015. Bark thickness and fire regimes. Functional Ecology 29(3):315-327.

Poberezhnaya, T.M. \& A.V. Kopanina 2011. The biogeochemistry and anatomy of plants in areas of recent volcanism. Contemporary Problems of Ecology 4(2):212-217 (in Russian and English). [Побережная Т.М., Копанина А.В. 2011. Биогеохимические и анатомические особенности растений в местах проявления современного вулканизма // Сибирский экологический журнац. № 2. C. 285-292].

Prozina, M.N. 1960. Botanical micro-technology. Vysshaya shkola, Moscow, 206 pp. (in Russian). [Прозина M.H. 1960. Ботаническая микротехника. М: Высшая школа. 206 c.].

Richardson, S.J., D.C. Laughlin, M.J. Lawes, R.J. Holdaway, J.M. Wilmshurst, M. Wright, T.J. Curran, P.J. Bellingham \& M.S. McGlone 2015. Functional and environmental determinants of bark thickness in fire-free temperate rain forest communities. American Journal of Botany 102(1):1-9.

Rosell, J.A., M. Castorena, C.A. Laws \& M. Westoby 2015. Bark ecology of twigs vs. main stems: functional traits across eighty-five species of angiosperms. Oecologia 178(4): 1033-1043.
Ruas, E.A., C.F. Ruas, P.S. Medri, C. Medri, M.E. Medri, E. Bianchini, J.A. Pimenta, L.A. Rodrigues \& P.M. Ruas 2011. Anatomy and genetic diversity of two populations of Schinus terebinthifolius (Anacardiaceae) from the Tibagi River basin in Paraná, Brazil. Genetics and Molecular Research 10(1):526-536.

Schafer, J.L., B.P. Breslow, M.G. Hohmann \& W.A. Hoffmann 2015. Relative bark thickness is correlated with tree species distributions along a fire frequency gradient. Fire Ecology 11(1):74-87.

Schweingruber, F.H. 2007. Wood Structure and Environment. Luxembourg, 279 pp.

Stasova, V.V., L.N. Skripalschikova, O.N. Zubareva \& A.I. Tatarintsev 2011. Structure and development of Betula pendula (Betulaceae) trunk tissues under conditions of anthropogenic pollution. Rastitelnye Resursy 47(2):66-75 (in Russian). [Стасова В.В., Скрипальщикова А.Н., Зуб̆рева О.Н, Татаринцев А.И., 2011. Строение и развитие тканей ствола Betula pendula (Betulaceae) в условиях антропогенного загрязнения // Растительные ресурсы. Вып. 47, № 2. С. 66-75].

Suzuki, E. 1999. Diversity in specific gravity and water content of wood among Bornean tropical rainforest trees. Ecological Research 14:211-224.

Terrazas, T. \& T. Wendt 1995. Systematic wood anatomy of the genus Tapirira Aublet (Anacardiaceae) - a numerical approach. Brittonia 47(2):109-129.

Zharkov, R.V. 2014. Thermal sources of southern Kuril Islands. Dal'nauka, Vladivostok, 378 pp. (in Russian). [Жарков P.B. 2014. Термальные источники Южных Курильских островов. ВАадивосток: Аальнаука. 378 с.]. 